\title{
MODEL ARTIKEL SURAT KABAR SEBAGAI ALTERNATIF BAHAN AJAR MATA KULIAH MENULIS
}

\author{
${ }^{1)}$ Dede Abdurrokhman, ${ }^{2)}$ Tamtam Kamaluddin \\ ${ }^{1,2)}$ Program Studi Pendidikan Bahasa dan Sastra Indonesia, STKIP Siliwangi
}

\begin{abstract}
ABSTRAK
Mahasiswa Prodi Pendidikan Bahasa dan Sastra Indonesia sudah tentu harus memiliki kemampuan menulis. Mereka secara formal digembleng melalui mata kuliah Menulis. Namun, kenyataannya tampaknya belum sesuai dengan harapan. Berdasarkan hasil pemeriksaan tugas mata kuliah Kepenulisan Karya Ilmiah Populer masih banyak yang belum memenuhi kemampuan yang layak. Ini terutama dalam tugas membuat artikel yang akan di muat di media massa. Berdasarkan persoalan ini, menarik untuk diteliti tentang model tulisan artikel surat kabar atau koran. Diharapkan hasil penelitian ini dapat memberi alternatif pengayaan bahan ajar Mata Kuliah Menulis di Prodi Bahasa dan Sastra Indonesia. Untuk itu, perlu diketahui hal mendasar dari tulisan artikel surat kabar atau koran, model apakah yang digunakan dalam penulisan artikel koran tersebut sekaligus bagaimana dapat dijadikan atau disusun sebagai alternatif bahan ajar dalam mata kuliah menulis. Hasil penelitian ini menyimpulkan bahwa karakteristik artikel pada surat kabar atau Koran adalah sebagai berikut. (a).Judul artikel koran itu singkat, specifik, informal, dan provokatif ; (b).Topik artikel koran itu aktual dan menarik, baik topik yang bersifat orisinal maupun berupa ide lanjutan (tulisan tanggapan, pengembangan); (c). Organisasi karangan artikel koran itu umumnya memiliki komposisi seperti : pendahuluan, isi, dan simpulan/penutup; permasalahan, uraian/bahasan, dan jawaban; tulisan ada yang disajikan atas sub topik, atau tanpa sub topik; paragraf yang digunakan merupakan paragraf yang padu; (d).Artikel Koran itu menggunakan bahasa yang lancar dan lugas sehingga enak dibaca dan mudah dipahami; (e). Diksi atau kata-kata yang digunakan dalam artikel koran itu umumnya kata bermakna denotatif; di samping, digunakan pula kata-kata bermakna konotatif yang jumlahnya tidak sebanyak denotatif; digunakan pula kata atau ungkapan khusus yang bermakna tertentu pula (sebagai tipikal) penulisnya; (f). Gaya tulisan artikel Koran itu umumnya bersifat serius, di samping terdapat pula gaya anekdot; (g). Nada tulisan artikel koran itu umumnya bernada informatif, disamping digunakan pula nada argumentatif, atau nada kritik; (h). Ukuran Artikel Koran itu umumnya berukuran sekitar 1.000-2.000 kata ; di samping terdapat pula yang berukuran di bawah 1.000 kata; atau berdasarkan hasil ketikan, sekitar 5-10 halaman kuarto dengan jarak dua spasi (sekitar 10-15 kilo bait, ketik komputer); (i). Waktu pemuatannya artikel koran, prinsipnya terbagi atas dua kelompok yaitu artikel yang termasuk memiliki calender of event, seperti artikel bertema tentang hari-hari besar nasional/keagamaan, dan yang diluar calender of event (eksklusif);
\end{abstract}

Kata Kunci: model karakteristik artikel koran

\begin{abstract}
Students Prodi Indonesian Language and Literature should certainly have the ability to write. They are formally trained through courses Writing. However, the reality seems to have not been in line with expectations. Based on the results of the task subjects Popular Scientific Authorship still many who do not meet the appropriate capacity. This is particularly the task of creating articles that will fit on the media. Based on these issues, interesting to study about the model writing newspaper articles or newspapers. We hope this research can provide alternative teaching material enrichment courses Prodi Writing in Indonesian language and literature. For that, keep in mind the basics of writing a newspaper article or newspaper, the model is used in writing newspaper articles is at once how it can be used or prepared as an alternative teaching materials in the course menulis.Hasil this study concluded that the characteristics of the article in a newspaper or Newspapers are as follows. (a) .Judul newspaper article was brief, specifik, informal, and provocative; (b) the actual newspaper article .Topik and attractive, both topics that are original or in the form of advanced ideas (written responses, development); (c) essay. Organisasi newspaper article generally has a composition such as: introduction, contents, and conclusions/ cover; issues, description / discussion, and answers; anyone writing on sub-topics presented, or without a sub-topic; paragraph used a coherent paragraph; (d) The paper .Artikel use the language
\end{abstract}


fluently and straightforward so readable and easily understood; (e). Diction or words used in a newspaper article that generally worded denotative; in addition, also used the words connotative meaning that the amount is not as much as denotative; also used specific words or phrases that certain meaningful anyway (as typical) author; (f). Newspaper article writing style was generally serious, in addition there is also anecdotal style; $(\mathrm{g})$. The tone of writing a newspaper article that generally pitched informative, besides also used argumentative tone, or tone of criticism; (h). The newspaper article size generally measuring approximately 1,000-2,000 words; in addition there are also measuring under 1,000 words; or based on the results of typing, about 5-10 quarto pages with a distance of two spaces (around 10-15 kilos of bait, type of computer); (i). Pemuatannya time newspaper articles, principally divided into two groups: the article that includes having a calendar of events, such as themed article about the great days of national/ religious, and beyond calender of event (exclusive);

Keywords: model of the characteristics of a newspaper article

\section{A. PENDAhuluan}

Keterampilan menulis, memang sering dipandang sebagai keterampilan berbahasa yang paling akhir dari keseluruhan keterampilan berbahasa, dan juga sering dianggap sebagai keterampilan yang paling sukar (Alwasilah.2004). Keterampilan menulis (writing skills) harus melibatkan keterampilan ortografi, struktur, dan kosa kata; di samping memil;iki keterkaitan erat dengan tiga keterampilan berbahasa, seperti menyimak (listening skills, berbicara (speaking stkills), dan lebih-lebih dengan keterampilan membaca (reading skills) (Tarigan,2000).

Walaupun demikian keterampilan menulis itu dapat dipelajari. Mahasiswa Prodi Pendidikan Bahasa dan Sastra Indonesia sudah tentu harus memiliki kemampuan menulis. Mereka secara formal digembleng melalui mata kuliah Menulis. Namun, kenyataannya tampaknya belum sesuai dengan harapan. Berdasarkan hasil pemeriksaan tugas mata kuliah Kepenulisan Karya Ilmiah Populer masih banyak yang belum memenuhi kemampuan yang layak. Ini terutama dalam tugas membuat artikel yang akan di muat di media massa.

Hal seperti di atas tentunya sangat ironis, manakala melihat kecenderungan tuntutan lulusan pendidikan tinggi dan orientasi dunia kerja yang mengarah kepada kemampuan nyata (what one can $d o$ ). Keterampilan yang memadai yang dimiliki mahasiswa Prodi Pendidikan bahasa dan Sastra Indonesia dalam menulis tentunya juga tidak bertentangan dengan profesinya sebagai guru (kelak). Justru, bahwa guru termasuk kelompok cerdik pandai harus dibuktikan, yang salah satunya yaitu mampu menulis, termasuk menulis artikel pada surat kabar atau Koran.
Pokok bahasan artikel akan lebih kaya dan komprehensif jika perkuliahan tersebut didasarkan pada hasil penyelidikan yang factual atas berbagai tulisan artikel. Misalnya bagaimana model penulisan artikel. Hal ini akan lebih menarik manakala mahasiswa dihadapkan kepada pengalaman empirik, yakni melalui pengamatan langsung terhadap tuilisan artikel, untuk selanjutnya mereka mencoba berlatih membuatnya. Untuk itu dosen harus memiliki panduan sebagai bahan kajian artikel.

Berdasarkan persoalan di atas, menarik untuk diteliti tentang model tulisan artikel surat kabar atau Koran. Diharapkan hasil penelitian ini dapat memberi alternatif pengayaan bahan ajar Mata kuliah menulis di Prodi Bahasa dan Sastra Indonesia. Untuk itu, perlu diketahui hal mendasar dari tulisan artikel surat kabar atau koran, model apakah yang digunakan dalam penulisan artikel koran tersebut sekaligus bagaimana dapat dijadikan atau disusun sebagai alternatif bahan ajar dalam mata kuliah menulis.

\section{B. KAJIAN TEORI DAN METODE}

Banyak ahli yang menyatakan pandangannya mengenai karakteristik, beberapa di antaranya adalah Simanjuntak B. dan Pasribu(2001) menjelaskan bahwa karakteristik diterangkan dari karakterologi, yakni ilmu karakter yang mmemiliki keterkaitan dengan istilah tipologi, yaitu ilmu yang mengadakan penggolongan (tipe). Karakteristik yang dimaksud dalam penelitian ini adalah cirriciri khas atau tipe tertentu yang ada dalam artikel Koran, seperti: judul, topic, organisasi karangan, retorika, diksi, gaya tulisan, nada tulisan, ukuran (panjang pendek), waktu pemuatan, dansebagainya. Sedangkan model adalah, diartikan sebagai contoh, acuan, atau pola yang mengarah kepada pola struktur tulisan. Tulisan di Koran, 
seperti tulisan berita selalu menggunakn model penulisan pyramid terbalik.

Hal ini untuk mempermudah dan mempercepat pembaca menemukan pokok berita. Pernyataan tersebut sejalan dengan pendapat (Assegaf ; 2002 : 11) seperti berikut ini. Tujuan model penulisan piramida terbalik adalah untuk memudahkan khalayak pembaca yang bergegas, untuk cepat mengetahui apa yang terjadi dan diberitakan. Adakah model piramida terbalik ini berlaku pada setiap tulisan artikel di Koran?

Artikel sebagai salah satu dari jenis tulisan popular tidak gampang untuk didefinisikan. Sering, kata artikel dipertukarkan dengan opini. Karena itu, perlu dijelaskan secara rinci tentang pengertian artikel.

Artikel ialah tulisan tentang suatu masalah berikut pendapat dan pendirian penulisnya tentang masalah tersebut (Soesono,2003). Selanjutnya, Soeseno berpendapat bahwa artikel dapat pula tulisan tentang masalah berikut sikap atau pendirian penulisnya, atau berupa petunjuk pelaksanaan tentang suatu keterampilan menurut versi penulisnya. Artikel biasanya ditulis lebih panjang dan mendalam mengenai suatu masalah berikut sikap atau pendirian penulisnya, berdasarkan studi literatur tentang masalah yang sama dan pemecahannya sebagai hasil pemikiran yang mendalam. Biasanya hasil pemikiran pakar bidang keilmuan yang bersangkutan.

Mappatoto (1994) menerangkan arti Karya tulis lengkap dalam majalah, surat kabar, dan sebagainya,Tulisan nonfiksi, biasanya singkat dan lengkap, seperti berita dan karangan khas dalam surat kabar atau majalah,dan Karangan tertulis yang panjangnya tak tentu yang bertujuan untuk menyampaikan gagasan dan fakta dengan maksud untuk meyakinkan, mendidik, atau menghibur.

Penelitian ini merupakan penelitian kualitatif dengan metode deskriptif analisis, yaitu mendeskripsikan fakta-fakta yang kemudian disusul dengan kegiatan menganalisis data. Metode deskriptif digunakan karena penelitian ini menggambarkan dan menjelaskan data secara apa adanya. Hal ini sesuai dengan penjelasan Arikunto (1993:310) yakni bahwa metode deskriptif adalah metode yang menjelaskan data atau objek secara natural, objektif, dan faktual (apa adanya).

Adapun yang menjadi subjek dalam penelitian ini adalah beberapa artikel dari beberapa surat kabar atau Koran nasional yang terbit sepanjang tahun 2014. Adapun surat kabar atau Koran yang terpilih adalah Koran Pikiran rakyat dan Media Indonesia. Masing-masing dua artikel yang dapat dipilih dari surat kabar tersebut.

Judul artikel yang terpilih dan dijadikan objek penelitian ini adalah, 1) Pembangunan yang Mencemaskan hasil tulisan Iu Rusliana dari Pikiran Rakyat, 2)Mahalnya Buku, Dilema Edukasi Masyarakat Berperadaban hasil tulisan Sudarwan dari Media Indonesia, 3) Pelayan Publik Bergaya Enterprenuer hasil tulisan Khairul Rizal dari surat kabar Media Indonesia, dan yang terakhir 4) Belajar Bahasa daerah harus dimulai dari Rumah hasil tulisan Moh.Abdul Khak surat kabar Pikiran Rakyat.

\section{HASIL DAN PEMBAHASAN}

Hasil penelitian diperoleh dari 4 artikel data yang terkumpul terkait karakteristik model artikel surat kabar atau Koran Berdasarkan analisis terhadap artikel itu, maka dapat diuraikan tentang karakteristik artikel itu sebagai berikut.Judul artikel itu terdiri atas dua kata yaitu (yang mencemaskan), dan Pembangunan.Judul tersebut relevan dengan pokok bahasan, terutama relevan dengan persoalan aktual yang tengah mengemukan pada saat itu, yaitu tentang bagaimana pembangunan yang ada di Indonesia. Judul artikel itu provokatif, terlebih dengan digunakannya prasa yang mencemaskan, menjadikan pembaca dirangsang untuk mengetahui apa benar pembangunan di Indonesia mencemaskan? Judul itu refresentatif dalam mewakili keseluruhan isi tulisan karena isi tulisan itu mempersoalkan bagaimana pembangunan yang sesungguhnya dan seharusnya.

Sebagai bukti dapat dilihat contoh kutipan berikut ini."Pembangunan berbasis pemberdayaan dan keswadayaan inilah idealnya pembangunan. Rencana pembangunan sekecil apapun itu harus mendorong pemberdayaan dan keswadayaan rakyat" (paragraf ke-4).Judul artikel itu merupakan judul yang informative karena berupa prasa, yang tak mungkin digunakan dalam suatu tulisan ilmiah. Judul artikel itu telah menunjukkan hal yang khusus, yaitu tentang pembangunan yang mencemaskan.Topik pembahasan artikel itu actual, sejalan dengan persoalan yang sedang hangat dibicarakan topik termasuk eksklusif, tidak terlalu terbatasi oleh calendar of event. Walaupun 
demikian, topik tetap diangkat dari persoalan yang penting dan punya bobot aktualitas.

Proporsi antara bagian pendahuluan, isi, dan kesimpulan/penutup dalam artikel itu termasuk proposional, yaitu: $(20 \%-60 \%-20 \%)$.Sehingga pertimbangan ini menjadikan artikel tersebut berkomposisi "ideal" organisasi karangan dimulai dengan adanya paragraf yang menyajikan masalah. Hal ini dapat dilihat dari paragraf ke- 13 seperti dapat dilihat pada contoh kutipan berikut ini." Ada beberapa ciri pembangunan berbasis pemberdayaan dan keswadayaan. Pertama program dirumuskan bersama dengan masyarakat apa yang dibutuhkan.Kedua program difokuskan berdasarkan kebutuhan yang mendukung keberdayaan".Retorika, penggunaan bahasa mengalir sangat lancar dan lugas sehingga memunculkan gaya khas penulisnya.Misalnya, adanya kata pembangunan dibagi menjadi tiga model.

Pertama model "bagi-bagi kue". Jenis pembangunan seperti ini yang kini yang mendominasi. Ada anggaran yang disiapkan, kongkalikong dengan pengusaha, dan ada jatah yang dibagikan. Umumnya terjadi karena balas jasa atas investasi pengusaha kepada calon penguasa ketika membutuhkan biaya kampanye.(paragraf 2). Diksi, Kata-kata yang digunakan dalam artikel itu memiliki ciri penanda khas penulisnya. Hal ini seperti terungkap dalam kata-kata seperti; kongkalikong,balas jasa, mata anggaran, top down, pemberdayaan, keswadayaan, pelaksana amanah, dll.

Pada paragraf ini jelas pemilihan kata cukup mudah dimengerti sebagai berikut."Pelaksanaannya digerakkan oleh anggaran pembangunan Negara dan daerah. Ibarat kue, uang rakyat itu dianggap milik sendiri untuk dibagi. Di kalangan panitia pengadaan dinas, kementrian atau instansi pemerintah, ada istilah "bintang". Istilah "bintang" menunjukkan siapa yang memegang mata anggaran dan program tersebut di lingkungan birokrasi. Konon, pemegangnya setingkat anggota DPRD atau DPR, kepala dinas, bupati, wali kota, gubernur, direktur, dirjrn, bahkan menteri (paragraf ke-3).

\section{KESIMPULAN}

Judul artikel koran itu (a) singkat, specifik, informal, dan provokatif ; (b) Topik artikel koran itu aktual dan menarik, baik topik yang bersifat orisinal maupun berupa ide lanjutan (tulisan tanggapan, pengembangan); (c) Organisasi karangan artikel koran itu umumnya memiliki komposisi seperti : pendahuluan, isi, dan simpulan/penutup; permasalahan, uraian/bahasan, dan jawaban; tulisan ada yang disajikan atas sub topik, atau tanpa sub topik; paragraf yang digunakan merupakan paragraf yang padu; (d) Artikel Koran itu menggunakan bahasa yang lancar dan lugas sehingga enak dibaca dan mudah dipahami; (e) Diksi atau kata-kata yang digunakan dalam artikel koran itu umumnya kata bermakna denotatif; di samping, digunakan pula kata-kata bermakna konotatif yang jumlahnya tidak sebanyak denotatif; digunakan pula kata atau ungkapan khusus yang bermakna tertentu pula (sebagai tipikal) penulisnya; (f) Gaya tulisan artikel Koran itu umumnya bersifat serius, di samping terdapat pula gaya anekdot; (g) Nada tulisan artikel koran itu umumnya bernada informatif, disamping digunakan pula nada argumentatif, atau nada kritik; (h) Ukuran Artikel

Koran itu umumnya berukuran sekitar 1.000-2.000 kata ; di samping terdapat pula yang berukuran di bawah 1.000 kata; atau berdasarkan hasil ketikan, sekitar 5-10 halaman kuarto dengan jarak dua spasi (sekitar 10-15 kilo bait, ketik komputer); (i). Waktu pemuatannya artikel koran, prinsipnya terbagi atas dua kelompok yaitu artikel yang termasuk memiliki calender of event, seperti artikel bertema tentang hari-hari besar nasional/keagamaan, dan yang diluar calender of event (eksklusif); (j). Tata letak artikel koran dilihat berdasarkan peletakan/penempatannya, prinsipnya memiliki dua tempat yaitu yang ditempatkan pada kolom opini (berdampingan dengan editorial) dan yang ditempatkan diluar kolom opini (tidak berdampingan dengan editorial).

Hasil penelitian ini baru sampai pada tahap menyodorkan alternatif bahan ajar mata kuliah menulis "Penulisan Artikel", yang diperoleh atau disusun berdasarkan kajian empiric terhadap sejumlah artikel Koran. Oleh karena itu, efektivitas materi/bahan ajar yang meliputi karakteristik artikel Koran dan model artikel Koran ini belum teruji. Untuk itu disarankan ada upaya tindak lanjut untuk mengujicobakan hasil penelitian ini. Uji coba hasil penelitian ini dapat dilakukan oleh peneliti lain, yang berminat terhadap pengembangan mata kuliah menulis, khususnya "Penulisan Artikel". 


\section{E. DAFTAR PUSTAKA}

Akhadiah, Sabarti dkk.2000. Pembinaan Kemampuan Menulis. Jakarta: Erlangga.

Assegaf,Djafar.2003.Jurnalistik Masa Kini: Pengantar ke Praktek Kewartawanan.

Jakarta: Ghalia Indonesia

Badudu,J.S.1993.Cakrawala Bahasa Indonesia I Jakarta: Gramedia Pustaka Utama

Krashen, Stephen D. 1984. Writing: Research,Theory, and Application. New York: St.Martin's Press.

Kridalaksana, Harimurti. 2001. Kamus Linguistik. Jakarta: Gramedia Pustaka Utama.

Leech, Geoffrey. 1993. Prinsip-prinsip Pragmatik. Jakarta: UI-Press.Rahardi, Kunjana. 2005. Pragmatik: Kesantunan Imperatif Bahasa Imperatif Bahasa Indonesia. Jakarta: Erlangga.

Sudaryanto. 2005. Metode Linguistik. Yogyakarta: Gadjah Mada University Press.

Sugiyono. 2010. Memahami Penelitian Kualitatif. Bandung: CV Alfabeta.

Tarigan. 2008. Berbicara sebagai Suatu Keterampilan Berbahasa. Bandung: Angkasa

Wijana, I. Dewa Putu. 1996. Dasar-dasar Pragmatik. Yogyakarta: Andi Offset.

Wijana, I. Dewa Putu. 2009. Analisis Wacana Pragmatik. Surakarta: Yuma Pustaka.

Yule, George. 2006. Pragmatik (terjemahan). Yogyakarta: Pustaka Pelajar. 